\title{
Fotograferne og krigen i 1864
}

\section{Af Jørgen Slettebo}

Krigen i 1864 markerer fotografiets debut som krigsreportage i Danmark. Mange fotografer slog mønt af den enorme interesse for billeder - og der blev gjort mange krumspring for at tilfredsstille kunderne. Museumsinspektør Jørgen Slettebo fortæller her om fotografernes arbejde og påviser, at ikke alle de gamle optagelser kan betragtes som sanddru kilder.

Hver dag bringer aviser og fjernsyn de nyeste og mest aktuelle fotos fra døgnets begivenheder. Hele verden dakkes af årvågne fotografer, der arbejder overalt, hvor der sker eller kan ventes at ske noget, der skønnes at have interesse. Pressefotograferne tager langt, langt flere billeder, end der overhovedet er mulighed for at viderebringe. På brøkdele af et sekund fastfryses en begivenhed $\mathrm{i}$ en serie billeder, som man så kan vælge iblandt.

Der er foregået en lang udvikling fra det første billede, som det i 1826 lykkedes J.N. Niépce at fastholde efter en eksponeringstid på 8 timer. Selv om det snart efter lykkedes L.J.Daguerre at demonstrere optagelser med en eksponeringstid på under tre kvarter, så var det alligevel begrænset, hvad man kunne fotografere - arkitektur og landskaber var foreløbig bedst egnet til den nye teknik. Det varede dog ikke længe, før mennesket vandt indpas $\mathrm{i}$ fotografierne, først stive, ofte med hovedet fastholdt $i$ en nakkestøtte, men hurtigt stadig friere, indtil det snart blev muligt at fotografere mennesket $i$ bevægelse. $^{1}$

\section{De første reportager}

De allerførste naturbilleder, franskmanden Daguerres og englænderen W.H.Fox Talbots, begge fra $1839-40$, blev taget lige ved deres hjem. Snart begyndte de første fotografer imidlertid at rejse ud for at tage billeder. Storbyerne, især London, Paris og Rom, blev de tidligste fotografiske mål, der bragte kendskab til arkitektur ud til videre kredse, men allerede omkring 1850 besøgte fotograferne også Ægypten og Indien. Grundlaget for en egentlig reportagefotografering var lagt. De tidligste reportagefotos er nok Delamottes optagelser fra opførelsen af Krystalpaladset i London 1853. Snart begyndte fotograferne også at interessere sig for tidens begivenheder og for tidens̀ samfundsforhold. Krige og sociale reportager blev oplagte emner for en del af fotograferne. ${ }^{2}$ 
Dagblade og tidsskrifter havde længe bragt illustrerede reportager fra aktuelle begivenheder. Tegnere og malere fulgte med hærene, rejste ud til naturkatastrofer eller opsøgte andre steder, hvor der skete noget. Deres skitser sendtes hjem til udgiverne, der lod dem skære i træblokke, xylografi, til gengivelse i aviser og tidsskrifter eller til salg som enkeltblade, måske endda kolorerede. Alle vigtigere begivenheder i Europa efter 1800 blev gengivet på denne måde, indtil fotografiet slog træsnitsreportagen ud. Endnu i Treårskrigen 1848-50, en halv snes år efter fotograferingens opfindelse og på et tidspunkt, hvor det var teknisk muligt at fotografere kanoner eller opstillede soldater, benyttede begge parter udelukkende tegnere og malere. De var til gengæld uhyre flittige. Billedproduktionen fra begge sider var meget stor og både i enkeltbilleder og tidsskrift-illustrationer spredtes illustrationer fra de enkelte krigsbegivenheder i store oplag. ${ }^{3}$

På det tidspunkt havde fotograferne andre steder $\mathrm{i}$ verden imidlertid netop fundet vej til krigsskuepladserne. De allerførste krigsfoto blev optaget under den amerikansk-mexikanske krig 1846-48, en amerikansk ryttergeneral, der rider ind $i$ en mexikansk by. ${ }^{4}$ Dernæst var der flere fotografer, som virkede $i$ krige samtidig med Treårskrigen, blot ikke her, men i Frankrig, Italien og Indien. Den franske mesterfotograf Hippolyte Bayard tog i 1849 en række billeder i Paris, som byen så ud efter revolutionen 1848, med nogle storartede og klare billeder af barrikader i gaderne. ${ }^{5}$ Samme år arbejdede en fotograf $i$ Rom, mens byen blev belejret af franske tropper. Han optog ødelagte bygninger, sammenskudte bastioner og opstillede kanoner - højst med en enkelt stift stående soldat på. I Indien deltog en sanitetsofficer John Mc Cosh både $\mathrm{i}$ den anden Sikh-krig (1848-49) og i Burmakrigen 1852-53. Han fotograferede sammenskudte pagoder, sprængte paladser og hærgede byer. ${ }^{6}$ Herhjemme kendes fra krigen 1848-50 kun nogle portrætfotos, som ikke er reportagebilleder. Således blev general Olaf Rye fotograferet 1849, kort før han faldt ved Fredericia. I Rendsborg benyttede flere af garnisonens officerer sig af de lokale fotografer, f.eks. daguerreotypist Louis Blanck, til at lade sig portrættere både før og lige efter krigen. ${ }^{7}$ Tilsvarende tilbød C.P.J.Fogh i Nakskov i 1851 at tage fotos af "soldater, der havde været med i felten « - evt. to på een gang. ${ }^{8}$

Det var dog først med Krimkrigen, at krigsfotograferingen virkelig slog igennem. Her deltog flere fotografer i kortere eller længere tid og enkelte officerer forsøgte sig også som amatørfotografer. Da den engelske korrespondent fra Times begyndte at skrive hjem om hærens og officerernes uduelighed, besluttede krigsministeriet at udsende en fotograf for at modbevise korrespondentens wumulige beretninger«. Efter flere mislykkede forsøg fik man sendt Roger Fenton af sted. Han indrettede en vogn med foto- og mørkekammerud- 
styr og nu kunne han, med fire heste, købt undervejs i Gibraltar, med fem kameraer og 700 glasplader køre rundt på Krim og fotografere, dog i god afstand fra kamphandlingerne. Han arbejdede der $\mathrm{i}$ et halvt år og forlod så Krim i 1855. Hans billeder blev dels gengivet som træsnit $\mathrm{i}$ »Illustrated London News«, dels udgivet af Th.Agnew i et værk med 160 fotografier. ${ }^{9}$

Krimkrigen blev den første krig, hvortil der sendtes fotografer med det udtrykkelige formål at lave reportage, at dokumentere begivenhederne. Fotograferingens tekniske stade tillod dog ikke at tage reportagebilleder i vor tids forstand, fotografier af selve kampene, men kun af visse situationer bag fronten.

De næste krige blev gengivet lidt mere virkelighedsnært, men heller ikke her var der dog tale om egentlige kampsituationer.

11. april 1862 udbrød den amerikanske borgerkrig, 6 uger efter at Abraham Lincoln ved Nordstaternes stemmer var blevet valgt til republikkens præsident. I fire år varede den hårdnakkede krig. Krigens ødelæggelser med 600.000 døde havde sat dybe spor hos begge krigens parter, der siden uafhængighedserklæringen 1776 havde stået sammen om i fællesskab at opbygge den unge nation.

Der var adskillige tegnere og fotografer på begge sider $\mathrm{i}$ krigen, og der blev taget talrige billeder i de år, da også Danmarks kampe i 1864 blev tegnede og fotograferede. De to største ugeblade havde ikke færre end 80 tegnere ved fronterne, og i Nordstaterne var på et tidspunkt udstedt over 300 pas til fotografer, der ønskede at komme i nærheden af krigsbegivenhederne. ${ }^{10}$ Fra begge sider i krigen blev der optaget talløse fotografier, både af afdelinger og militær udrustning, opstillet før kampene eller når de enkelte slag var overståede.

En af USA's mest fashionable fotografer var Mathew B. Brady. Han investerede $100.000 \$$ i udstyr og omkostninger ved at sende 20 fotografer til fronten. Den kendteste af disse blev Alexander Gardner, der i 1863 forlod Bradys firma og begyndte for sig selv. Gardner udgav i 1866 et 2-binds værk om krigen på grundlag af sine fotografier, og i 1875 købte krigsministeriet over 5.000 glasplader fra krigen af Brady. Adskillige andre fotografer valgte at lade deres optagelser gengive som kobberstik eller xylografier $\mathrm{i}$ aviser og tidsskrifter.

Det var stadig ikke teknisk muligt at fotografere selve krigshandlingerne. Billeder måtte tages før eller efter kampene. Men fotografierne var alligevel langt mere realistiske end de, der blev taget under Krimkrigen. Bl.a. A.J.Russell og T.O'Sullivan fotograferede de tilbageblevne døde soldater i en forladt skyttegrav, Joh. Reeke tog makabre billeder af de begravede, og især M. Bradys og A.Gardners drastiske billeder vakte bestyrtelse. Ikke mindst nogle fotografier, som A.J.Riddle og M.Brady tog af krigsfangelejren ved 
Andersonville og dens overlevende, gjorde et voldsomt indtryk og medvirkede til, at lejrkommandanten 1865 blev dømt for krigsforbrydelser og hængt A. Gardner fotograferede forberedelserne til henrettelsen. ${ }^{11}$

\section{Soldaterportrætter 1863-64}

Da det i løbet af efteråret 1863 blev klart, at en krig mellem Danmark og Preussen var en realistisk mulighed, begyndte man fra dansk side at indkalde både reserveofficerer og menige. En del skulle møde i december, andre ved årsskiftet og $\mathrm{i}$ løbet af januar samledes tropperne. Udsigterne til krigen virkede nok ikke særlig skræmmende på alle, idet erindringerne fra Treårskrigen var ganske positive, troen på Danevirkes styrke overordentlig stor og tilliden til hæren og dens udrustning præget af optimisme. Alligevel vidste man jo udmærket, at en krig var risikofyldt og udsigterne for den enkelte uoverskuelig. Mange lod sig derfor, også af hensyn til dem, der blev hjemme, fotografere før afrejsen. Det lille nemme visitkortformat $(\mathrm{ca} .9 \times 6 \mathrm{~cm})$ var blevet standardiseret i Paris 1854, og da både dronning Victoria og Napoleon III omkring 1860 lod deres portrætter sælge i netop dette format, blev det hurtigt uhyre populært. ${ }^{12}$ Der blev lavet foto-albums til denne størrelse, og overalt i Europa lod velhavende borgere sig fotografere til familie-albummet, der så desuden blev fyldt op med købte billeder af fædrelandets kongefamilie, kendte kunstnere og andre fremtrædende personer. ${ }^{13} \mathrm{Også} \mathrm{mange} \mathrm{højere} \mathrm{officerer} \mathrm{blev} \mathrm{portræt-}$ teret $\mathrm{i}$ visitkortfotos allerede omkring 1860. I talrige danske byer tilbød den stedlige fotograf at fotografere sådanne portrætter, og derved blev prisen på et visitkortfoto hurtigt ganske lav.

Ved indkaldelserne i vinteren 1863-64 var der derfor mange, både officerer og menige, der henvendte sig til den lokale fotograf for at lade sig forevige, $i$ daguerreotypi eller, $\mathrm{i}$ de fleste tilfælde, på papirfotos. Ønsket om at blive fotograferet, så familien kunne have et billede for øje hele tiden, kommer klart til udtryk $i$ et brev, som en menig, J.P.Hansen fra Horne på Fyn sendte d. 28. febr. fra garnisonen i Nyborg til sin kone Johanne Wikkelsø, der tjente på Horne Mark. Han skriver bl.a.:

"Jeg har i dag været inde hos en Phortograf og talt med ham, men det er

Portratfotos af soldater, optaget i 1864 og fremstillet $i$ visitkortformat. 0 verst fra venstre sekondlojtnant A. V.Jantzen, 20. regiment, 4. kompagni, foto F. Petersen, St. Kongensgade 21, Kbh. - Premierlojtnant A.A.B. Baumgart, svensk frivillig ved 5. regiment, foto Eduard Hansen, Odense. - Nederst fra venstre lojtnant v. Dewall, infanteriregiment $n r$. 55, foto F. Brandt, Flensborg. - Løjtnant v. Hellermann, 4. garderegiment til fods, 4. kompagni, foto J.E.Bögh, Klostergade 8, Arhus. Museet på Senderborg Slot. 

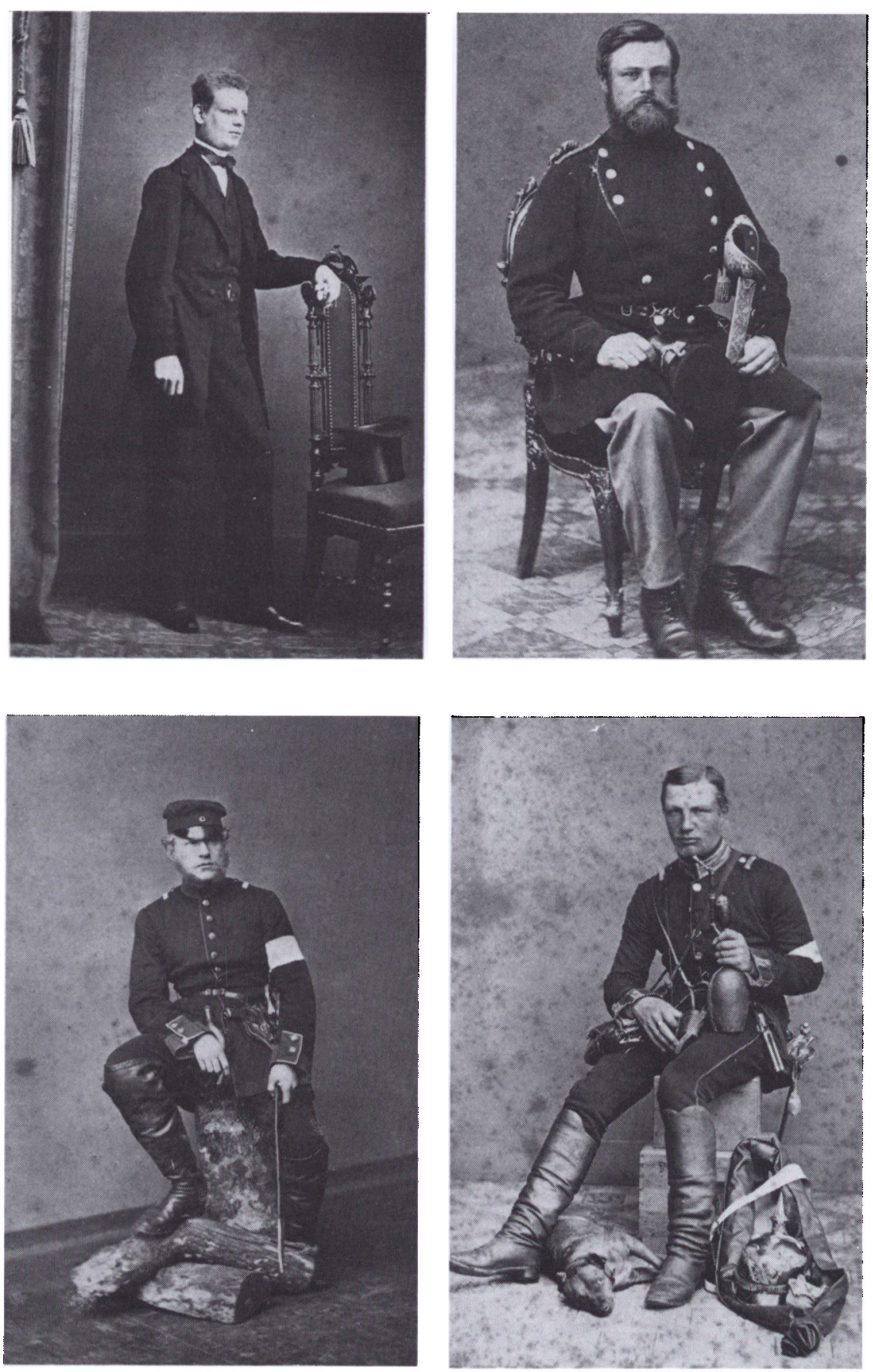
jo temmelig dunkelt Veir i dag, saa bliver det ikke saa smukt og det skulle det jo gerne være, men saa bliver det en Middagsstund nu en af Dagene, saa faaer Du mit Portræt først i næste Uge tænker jeg, jeg vee nok Du længes efter det ikkesandt lille Johanne ${ }^{14}$

I Roskilde annoncerede fotograf A. W. Rörbye i slutningen af december med at "enhver familiefader, som rejser til armeen, kan få sig selv samt hustru og børn fotograferede til halv pris«. I januar 1864 tog byens anden fotograf P.Chr.Sivertsen konkurrencen op med en meddelelse i samme avis, at også han leverer portrætter af indkaldte soldater med deres koner og børn til halv pris. ${ }^{15}$

Der kendes derfor soldaterbilleder fra 1864 fra mange steder $i$ landet: I København var det ikke mindst de lidt større fotofirmaer som hoffotograferne Georg E.Hansen og Jens Petersen, men også andre fotografer som Harald Cohen, Thora Hallager og Peter Most, Chr.Neuhaus, E.Rye og Co., R. Stieglers ateliér samt adskillige andre var virksomme. I de fleste provinsbyer optog de lokale fotografer også billeder af soldater.

Især i de større byer var der ligesom i Roskilde flere om at konkurrere, så priserne for portrætfotos var lave i vinteren 1863-64. I Odense fotograferede Carl Bech, der er blevet kaldt den første fastetablerede danske daguerreotypist i provinsen, E.Rye og J.P.J.Wahlmann, ligesom der var fotografer i bl.a. Assens og Nyborg på Fyn. I Århus var der to fotografer J.E. Bøgh, der var etableret som daguerreotypist allerede 1849 og Andr. Fritz, der egentlig var uddannet på Kunstakademiet som maler, særdeles virksomme. ${ }^{16}$ I efteråret 1863 og de første par måneder af 1864 fotograferedes de danske soldater, og efter Jyllands erobring blev modellerne i stort tal tyske og østrigske soldater i Århus, både enkeltvis og i grupper. Den kendte Ålborg-fotograf H.Tønies tog også mange soldaterbilleder ligesom en anden af byens fotografer, C.A.Zehngraf. Flere fotografer bl.a. i Fredericia, Horsens, Vejle og Viborg og enkelte andre jyske byer portrætterede også tyske soldater, A.F.L.Kayser i Vejle tog ligesom Bøgh og Fritz i Århus også billeder af østrigske soldater. ${ }^{17}$

Tilsvarende lod selvfølgelig mange tyske og østrigske officerer og menige sig afbilde, enten i deres hjemby før afrejsen til krigsskuepladsen eller, $i$ fuld uniform, på vej til fronten.

Alene i Museet på Sønderborg Slot er mere end 20 fotografer fra Berlin eller Berlins forstæder repræsenterede med soldaterportrætter. Det er især fotograf-firmaerne P. Biegner og Co., C. Brasch, Heinr. Graf, Gebrüder Grunder og C.Schwartz i Berlin, W.Paris og Co. i Neu-Ruppin og Selle i Potsdam, der besøgtes af officerer i 1863-64. Også i andre byer i Preussen optog fotograferne soldaterbilleder. Men da den indledende besættelse af hertugdømmet Holsten skete efter forbundsbeslutning, deltog der også troppestyrker fra 
andre tyske stater, Hannover og Sachsen. Derfor blev der også taget soldaterportrætter bl.a. i Hannover og Koblenz i efteråret 1863.

$\mathrm{Da}$ Holsten var blevet besat af de preussiske, østrigske, hannoveranske og sachsiske tropper $\mathrm{i}$ de sidste måneder af 1863 , benyttede mange lejligheden til at blive fotograferede enten i Hamborg eller i de holstenske byer. Fotografer som A.Siegmund og C.Junod i Hamborg og F. Brütt og J.G.Schwieger i Kiel var særlig benyttede, men også fra fotografer i Itzehoe, Kellinghusen, Lübeck og Segeberg kendes soldaterportrætter. Mange udnyttede ventetiden fra december til krigen brød ud d. 1 . februar til at lade sig fotografere. ${ }^{18}$

Efterhånden som den danske hær samledes i Sønderjylland og ved Danevirke, blev en del soldater fotograferede $i$ den by, hvor de var indkvarterede, Især hos fotograferne C.F. Brandt og Math.Kriegsmann i Flensborg blev adskillige taget, men også i Slesvig, Eckernførde, Haderslev, Sønderborg og Tønder benyttede flere soldater de lokale fotografer. Særlig energisk var fotograf J.J.Caprani i Aabenraa, der opgav, at han i lebet af 1864 tjente 5.000 rigsdaler alene på soldaterfotos. En anden, unavngiven fotograf, der under krigen arbejdede på Als, havde så travlt, at han for at spare tid lod soldaterne stille op til fotografering to og to med en halv meters afstand. Bagefter klippedes negativet så over på langs, så hver soldat kunne få sit portræt, mens fotografen kunne nøjes med det halve antal optagelser. ${ }^{19}$

Efter Danevirkes rømning d. 5.-6. februar rykkede de danske nordpå, fulgt af de tyske og østrigske tropper. Nu kunne de sønderjyske fotografer, der i de foregående par måneder havde fotograferet danske soldater, gå i gang med at tage billeder af nye kunder. Det var bl.a. H.Köhn og J.T.T.Baasch i Eckernførde, Heinr. Hess i Slesvig, I.Kriegsmann, C.F.Brandt og H.Eilmann i Flensborg samt H.B.Kier i Haderslev. Efterhånden som Jylland blev besat, benyttede de fremmede soldater som nævnt også de lokale fotografer i de byer, hvor de kom frem. De sejrende kunne nu ledsage deres beretninger til hjemmene i Preussen og Østrig af et nyoptaget portræt.

\section{Krigsfotografierne 1864}

Da krigen var begyndt d. 1 . februar 1864, blev krigsreportagen imidlertid straks mere interessant end portrætterne. Begge parter havde, nøjagtig som tidligere under Treårskrigen og som samtidigt i den amerikanske borgerkrig, tegnere og malere, der fulgte med hærene. De forsynede løbende tidens presse med forlæg, der benyttedes til xylografier. Illustreret Tidende i København og Illustrierte Zeitung i Berlin var hovedaftagere, men også The Illustrated London News og det franske Lillustration bragte hele tiden illustrerede reportager 
fra krigen..$^{20}$ Tegnerne fra de krigsførende parter var langt fra objektive - egne troppers tapperhed understregedes stærkt. De danske tegnere var tilbøjelige til at lægge vægt på modstandernes mængde, og vise den lille nations tapre kamp under ulige vilkår, mens de tyske tegnere fremstillede de danske befæstningers styrke stærkt overdrevet. De engelske og franske tegnere stræbte nok mere efter at være objektive, men var samtidig interesserede $i$ at sende så dramatiske billeder som muligt hjem til læserne.

Helt utrolig flittig var den tyske tegner Aug.Beck, der var i fuld gang allerede ved forberedelserne til forbunds-eksekutionen og som fortsatte med de tysk-østrigske tropper op gennem Jylland. Han kom helt til Nykøbing Mors og Limfjorden og nåede en udflugt til Skagen. Fra belejringen af Dybbøl tegnede han dels kampen ved Bøffelkobbel 22. februar og kampen om skanse IV d. 18. april, og ved erobringen af Als d. 29. juni var han tilbage og fulgte overgangen og kampene i $\mathrm{Kxr}$. Men der var mange andre tegnere og malere med - Otto Fikentschker, Wilh. Camphausen og L. Burger var blandt de flittigste. ${ }^{21}$ De leverede dels til tidsskrifter, dels til de forlag, som udsendte illustrerede værker om krigen. Også de store billedforlag som Oehmigke og Riemschneider i Neu-Ruppin og E.G.May i Frankfurt, der havde specialiseret sig i populære, farvelagte tryk, udgav blade med billeder fra krigen. Tilsvarende udgav flere danske forlag bøger og enkeltbilleder. Især J.Strandberg udsendte adskillige billeder med tekst, of test som illustrerede skillingsviser. Talrige danske malere som Otto Bache, Carl Baagøe, V.Fauerholdt, C.Neumann, Niels Simonsen og Fr.Visby både tegnede og malede. Flere, især Otto Bache og Niels Simonsen, benyttede efter krigen, ligesom den tyske Wilh.Camphausen, en del af deres skitser som udgangspunkt for store malerier med motiver fra kampene.

Fotografierne skulle, i modsætning til tegningerne, ikke kunne lyve, men fortælle sandheden. Da man ikke kunne gengive kamphandlingerne som tegnerne kunne, blev de nok mindre dramatiske, lidt mere kedelige, men de virkede også mere sandfærdige og realistiske. Imidlertid var det ikke muligt at optage billeder direkte ved fronten. Det var nemlig nødvendigt at fremkalde negativerne inden 20 minutter efter optagelsen, og fotografen måtte altså medbringe hele sit mørkekammer-udstyr sammen med sit kamera. Dette omfattende og pladskrævende udstyr kunne ikke bringes direkte med ind i kamplinien. Desuden var den fotografiske proces på den måde meget tid-krævende.

Enkelte billeder blev optaget af lokale fotografer, især af F.Brandt, Wilh. Dreesen og Heinr. Hess, alle tre fra Flensborg, hvorimod M. Kriegsmann, der i Flensborg havde optaget talrige soldaterportrætter, ikke vides at have taget billeder fra krigsskuepladsen. ${ }^{22}$ I Fredericia tog H.C. Bentzen billeder både før og efter byens erobring. ${ }^{23}$ Mærkeligt nok synes de to Sønderborg- 
fotografer Peter Andersen og F.W.Weide, der begge virkede i $1864 \mathrm{og}$ som optog portrætfotos af flere danske officerer og menige, ikke at have taget billeder fra krigsbegivenhederne. Nogle billeder fra årene efter 1864 af Sønderborgs genopbygning er derimod vistnok taget af P. Andersen. ${ }^{24}$

Men der var enkelte fotografer, der ligefrem specialiserede sig i krigsfotografier.

Fra København sendte hoffotograferne Jens Petersen og Georg E.Hansen begge fotografer til krigsskuepladsen. For G.E.Hansen fotograferede bl.a. J.C.F.W.Schrøder og F.C.S.Weller. Da billederne imidlertid som regel kun blev forsynede med firmanavn, er det ikke muligt af afgøre, hvem der rent faktisk har taget det enkelte billede, eller om de to hoffotografer overhovedet selv var med i Sønderjylland. Schrøder tog især stereoskop-billeder, d.v.s. to optagelser af samme motiv, hvor apparatet er flyttet en smule. Ved at betragte billederne gennem et særligt apparat, giver det en 3-dimensional virkning. Han var i øvrigt så uheldig at blive taget til fange af preusserne, så han kunne ikke fotografere i krigens sidste del. ${ }^{25}$ En tredie fotograf, der fulgte hærens tilbage-

Stereoskop-foto af danske soldater i en af skanserne på Dybbøl, for den tyske beskydning havde medfort storre odeloggelser. Udfort og solgt fra kgl. hoffotograf Georg E. Hansens firma, sandsynligvis optaget forst $i$ marts 1864 af W.Schroder. Billederne er taget med lidt forskudt udgangspunkt, så der er kommet flere kugler med på højre billede. Museet på Sonderborg Slot.

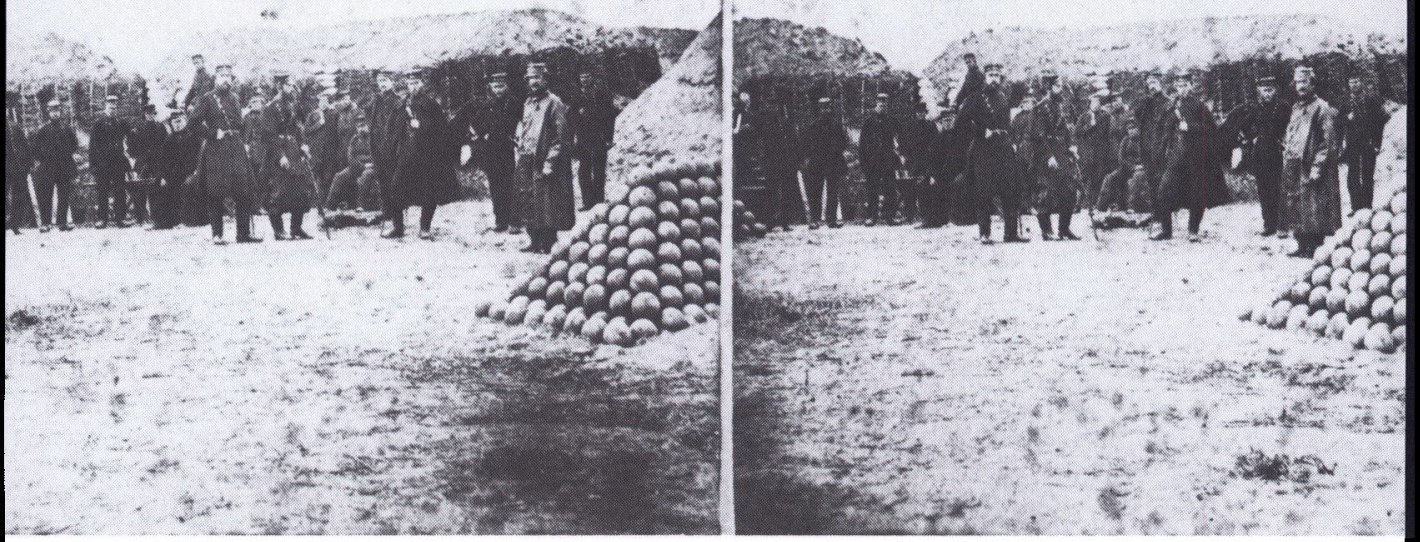


tog op gennem Jylland indtil Aarhus, var Andr. Fritz. Han var også inde ved Langaa for at fotografere ødelæggelsen af broen. Hos Fritz arbejdede bl.a. fotograf I.F.Dresler, men også her er billederne normalt blot forsynede med firmanavn.

Fra Berlin kom ligeledes flere fotografer. Flest billeder blev optaget af Heinr. Graf eller af hans medarbejder, Ad.Halwas, men også firmaet J.Jamrath und Sohn var med og tog adskillige fotografier. H.Graf (eller A.Halwas) virkede især i Sundeved, men tog også billeder i enkelte af de ødelagte skanser efter d. 18. april. Han eller en assistent kom igen i juni efter erobringen af Als og tog flere billeder af ruiner i Sønderborg. Derimod synes han ikke at være fulgt med hæren op i Jylland.

Mest kendte er imidlertid de mange billeder, der blev taget af F. Brandt fra Flensborg og C.Junod fra Hamborg. De udnævntes begge til hoffotografer hos Prins Friedrich Carl af Preussen, der var den øverste chef for den preussiske del af den preussisk-østrigske hær. C.Junod mærker ligefrem sine billeder: "Aufgenommen auf Befehl S.K. Hoheit des Prinzen Friedrich Carl von Preussen«. I en annonce for en serie på 21 billeder fra Dybbøl i tidsskriftet »Ueber Land und Meer« fra juni 1864 tilføjer han, at de er "gleich nach der Erstürmung aufgenommen . $^{26}$ Det siges da også almindeligvis, at hans billeder fra de erobrede skanser blev taget d. 19. april, dagen efter stormen. Foruden den lille serie i visitkortformat udsendte han en serie på 35 fotos, der solgtes opklæbede, dels i størrelse $16,5 \times 22,5 \mathrm{~cm}$, dels på karton med fotos på $23,5 \times$ $30 \mathrm{~cm}$. Hele denne serie er alene fra Dybbøl. Her optog han helt systematisk hver enkelt skanse fra I-X med to fra hver, nemlig et udefra og et af skansens indre. Hertil kom så motiver fra forbindelseslinierne, brohovedskansen, møllen og adskillige flere. Andre billeder fra Junods atelier, men måske optaget af en medarbejder, var en serie på 20, af den østrigske flåde, mens den lå i Cuxhaven. Han var med fra krigens begyndelse i Rendsborg og ved Mysunde, han optog flere billeder fra det forladte Danevirke, og var senere i Haderslev, Fredericia og Kolding. I alt synes han i 1864 at have optaget over 200 fotos, som så solgtes i flere forskellige udgaver. Junod optog mange af sine billeder som stereoskop-fotos. Ved udgivelsen af sine større billeder kunne han så hyppigt bruge det bedste af de to for at få den skarpeste gengivelse. Han kunne på den måde ud fra sine godt 200 optagelser tilbyde kunderne adskillige variationer.

Fotograf Chr. Fr. Brandt, der siden 1852 arbejdede i Flensborg, var endnu flittigere og hans billeder ofte af en højere kvalitet end Junods. Han annoncerede hyppigt $i$ lokale blade og var optaget $i$ hertugdømmernes adressebog fra 1853. I 1862 tilbød en Flensborg-boghandler i Dansk Boghandlertidende 16 portrætfotos, mest af kendte lokale folk, men også 5 af de kendteste danske 


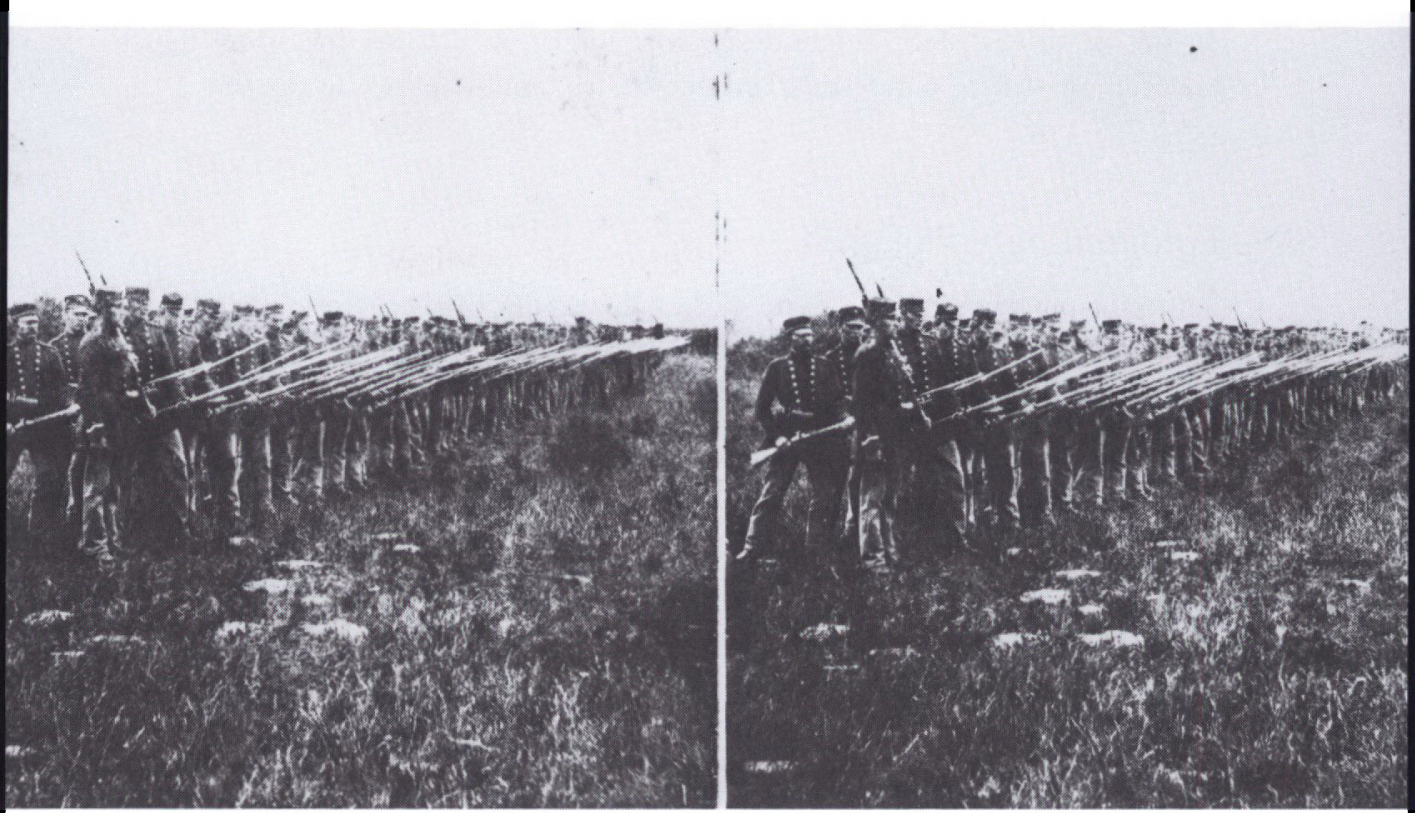

Stereoskop-foto af dansk soldatergruppe, opstillet klar til angreb. Billedet er udgivet af Georg E. Hansen og optaget uden for kampzonen, muligvis fra en eksercits. Der kendes en hel rakke sádanne fotos af danske soldater, parate til at trade i aktion, men alle optagne i ovelsessituationer. Museet pd Sonderborg Slot.

officerer fra Treårskrigen var iblandt dem. I 1864 blev han Hofphotograf S.K.H.d. Prinzen Friedrich Carl von Preussen«. Efter krigen ændredes det til »Kgl. Preuss. Hofphotograph«. Brandt vandt i årenes løb adskillige medailler for sit arbejde og deltog i en række udstillinger, bl.a. i Berlin og Paris. ${ }^{27}$

Hans billeder fra 1864 er nok knap så systematiske som Junods. Han har således åbenbart ikke vandret over Dybbøl Banke fra skanse til skanse. Der kendes ingen fotos fra hans hånd fra skanse I, II og III, og de er heller ikke så regelmæssigt opdelte med et ydre og et indre foto fra hver skanse. Til gengæld suppleres selve skansebillederne af talrige andre billeder fra forterrænet, fra Sottrup, Nybøl, Adsbøl og flere andre steder, fra en rakke enkelte batterier og en del panorama-billeder. Her udmærker to fotos i dobbelt bredde sig. Det ene viser skanseområdet set fra 1. tyske angrebsparallel, det andet viser udsigten mod Dybbøl fra udsigtsposten ved Gammelmark. De er sat sammen af flere optagelser, hvilket bedst ses på udsigten over Vemmingbund. Også Brandt har billeder fra flere steder op gennem Jylland, bl.a. Aabenraa, Kolding og Vejle. Længere nordpå kom han åbenbart ikke i 1864. Til gengæld har han dækket bogstavelig talt hele hertugdømmet Slesvig fra nord til syd 
og fra øst til vest. Han fulgte desuden sejren op med fotos af erobret dansk materiel og af flere mindesmærker, der rejstes umiddelbart efter krigen.

\section{Fotografi og virkelighed}

Som krigsreportage var de fleste af de billeder, der blev optaget under krigen 1864 mærkbart mere realistiske og faktisk oplysende end fotografierne fra Krimkrigen. På den anden side var de langt fra så drastisk-realistiske som de, der blev optaget på samme tid i den nordamerikanske borgerkrig. De viste ruiner, ødelagte kanoner og sønderskudte skanser, men ingen døde, ingen faldne soldater. Selv lazareth-billederne viste kun de pænt forbundne sårede med stokke og krykker, men først optaget efter at de er kommet op igen som rekonvalescenter efter operationerne.

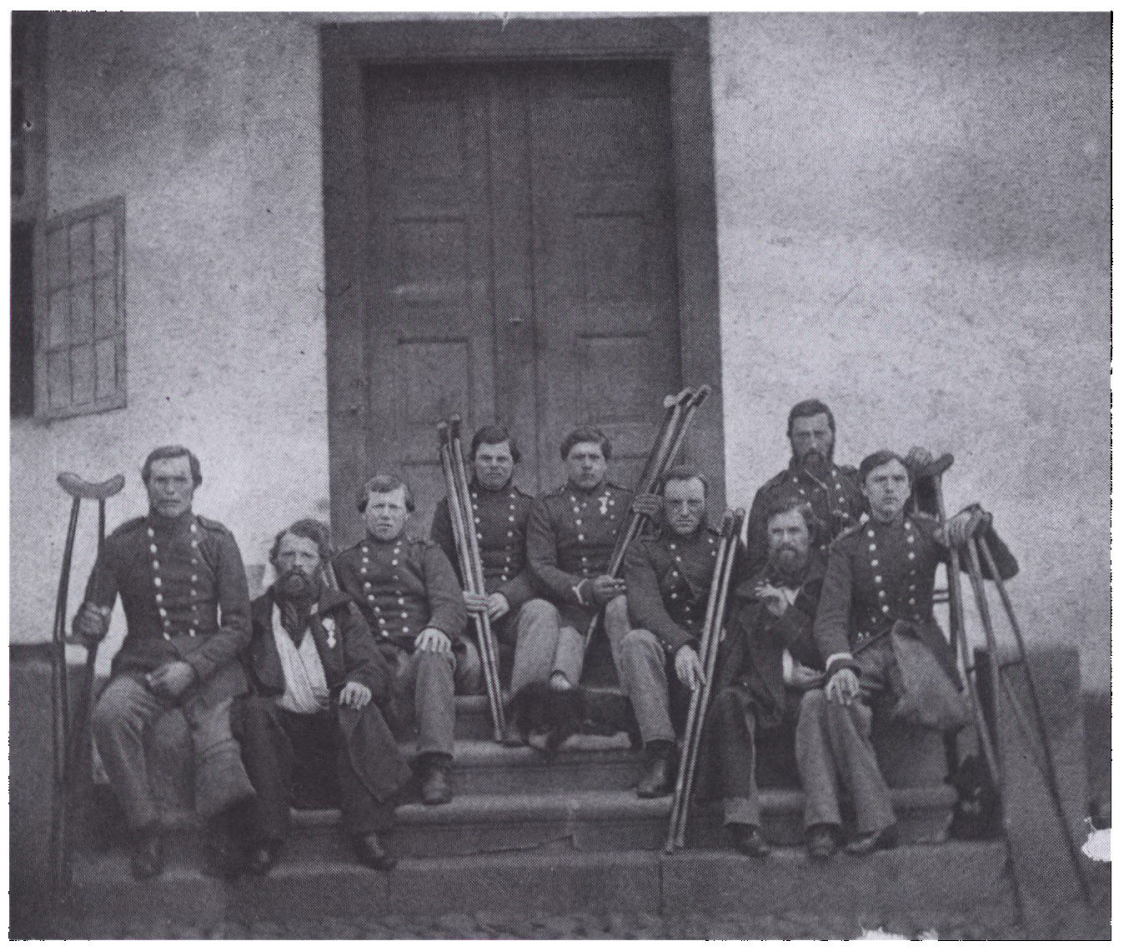

Särede danske soldater ved lazarettet pả Aalholm. Som alle lazaret-fotos viser dette rekonvalescenter efter at de er kommet sig nogenlunde - krykker eller armslynge kunne gd an, men ingen blod, intet operationsbord. Ubekendt fotograf. Fot. i Det kgl. Bibliotek. 
Billedmængden i dag er helt overvældende og der er en tilbøjelighed til at mene, at billedreportagerne, hvad enten det nu er levende billeder via fjernsynet eller øjebliksfoto i aviserne, gengiver virkeligheden. Ganske vist er det almindelig kendt, at der kan laves om på fotografierne uden at det altid umiddelbart kan ses. Mange officielle statsmands- eller fyrsteportrætter er omhyggeligt retoucherede, men ofte går man langt videre. Mest kendt er vel et par fotografier fra Rusland, hvor man på det første, fra 1920, ser Lenin på en talerstol med Trotskij på talerstolens trin, mens den senere udgave, der blev den officielle efter Trotskijs fald i 1929, har fået Trotskij bortretoucheret. ${ }^{28}$ Af samme type er et par fotos fra Kina, det ene fra 1936 med Mao sammen med tre af hans vigtigste medarbejdere, hvoraf den ene senere blev retoucheret væk fra gruppen. ${ }^{29}$ Endnu nyere er et par billeder fra Prag, hvor Dubček, er blevet fjernet på det, der publiceredes efter hans afsættelse. ${ }^{30}$ Også adskillige levende billeder, især i dokumentarfilm, har i nyere tid været udsat for tilsvarende indgreb.

Også i Danmark har man adskillige eksempler på, at fotografier ud fra mere eller mindre politiske formål er blevet retoucherede. Helt uskyldige virker nogle kort fra postkortfirmaet Biehl, der af en række billeder fra Kongeågrænsen udsendte to udgaver, en med tyske flag og en med danske. Så kunne de sælges til en meget større kundekreds. Mere klart politisk er et foto af kong Christian X, der på sin genforeningstur i 1920 besøgte Aabenraa Rådhus. På gavlen af nabohuset var malet en stor tysk reklame, der klart læses på fotografiet. På det billede, der kom $i$ handelen som et af en serie om Genforeningen, er hele reklamen retoucheret bort, så kongen ses mod en hvid gavl. På en fornyet udgave af billedet blev der ovenikøbet indføjet et meget stort Dannebrogsflag, der dækker gavlen. ${ }^{31}$

Retouchering af fotografier er imidlertid ikke af nyere dato. Helt fra fotografiets allerførste tid kunne man retouchere. På verdensudstillingen i Paris 1855 viste en tysk fotograf forskellen, idet han, side om side, udstillede et uretoucheret foto og det samme med den retouchering, som han selv havde udviklet. ${ }^{32}$ Mange større fotofirmaer havde fast ansatte retouchører. Hoffotograf Jens Petersen, havde i 1860 'erne ansat "retouchør Eduard Hansen ${ }^{33}$ og hoffotograf Georg E.Hansen beskæftigede i 1861/62 M.A.Sommer i 3 måneder for at lave 10.000 kopier af et foto af prinsesse Alexandra til brug for det engelske marked. ${ }^{34}$ Den franske fotograf Bouille, der i 1845 fotograferede i en pavillon med glastag i Tivoli, reklamerede med, at han leverede "portrætter, der i ingen henseende vise personerne ældre, end de er «. ${ }^{35}$ Der var dog også tidligt kritik af den megen retouche. I 1872 kritiseres fotograf L. Hartmann for at bruge for megen farve, og i 1863 reklamerede fotograferne A. Brütt og L.Olsen hver for sig med, at de $» n u$ leverer uretoucherede fotos ${ }^{36}$ 
De tidlige fotografer benyttede imidlertid ikke blot retouche i deres billeder. Flere arbejdede med sammenklippede negativer, hvoraf de skabte større kompositioner. Man kunne sammensætte to eller flere negativer, enten ved klipning eller ved afskærmning af de enkelte dele, så negativerne til sidst resulterede i et sammenhængende positiv. Det blev til store, meget populære, fortællende scener, ofte med mange personer på, og de kunne sælges i store oplag. Det gjaldt den berømte engelske fotograf Oscar Rejlander, der i 1850'erne, ved afskærmningsmetoden, skabte komplicerede scener med mange figurer, ofte $i$ noget sentimentale scenerier. Den samtidige H.P. Robinson benyttede sammenklipning af negativer til sine billeder. ${ }^{37}$ Sådanne fotos kaldtes »kombinationsbilleder«. De solgtes opklæbede på karton med trykt ramme og et ofte til billedet digtet vers, således som det senere i Danmark kendes med det populære "De sønderjyske piger« fra $1879 .{ }^{38}$ Overalt i Europa blev denne billedtype yndet og solgt $i$ store mængder.

Ikke alle fotografier blev lige klare, og mange blev derfor tydeliggiort ved

Skanse IV med resterne af det sonderskudte blokhus og et par delvis odelagte kanoner, enkelte opstillede og en gruppe siddende tyske soldater og et nyopstillet tysk spidstelt midt $i$ den erobrede skanse. Foto efter 18. april af C.Junod, Hamborg. Museet pd Sonderborg Slot. 
retouche. Men desuden var der forlag, der ikke var så heldige at have enten fotografer eller tegnere med nær fronten, men som på den anden side gerne ville være med i den salgssucces, som mange af disse billeder var. De benyttede da ofte fotografier, som de "forbedrede« ved kraftig retouche eller ved overmaling, så de originale optagelser blev mere eller mindre skjult. På den måde kunne man kalde sin udgave mautentisk " uden at den var identisk med forbilledet, og uden at man kom for tæt på reglerne om ophavsret. ${ }^{39}$ Olin i Sønderborg, der som een af mange søgte at efterligne "De sønderjyske Piger» for at få andel i successen, lagde sig så tæt op ad forbilledet, at det snarest må kaldes et direkte plagiat. ${ }^{40}$

Flere fotos 1864 kendes i variationer, der adskiller sig fra hinanden ved små ændringer. De skyldes ofte retouchering, men i mange tilfælde snarere, at fotografen har lavet flere optagelser, hvor kameraet måske er flyttet lidt mellem hver, og hvor soldaterne, der har været opstillet som staffage, er gået til og fra mellem optagelserne. Som eksempel kan nævnes to fotos af Brandt fra

Samme billede af skanse $I V$, udfort efter et starkt overmalet positiv, med bdde bortretoucherede enkeltheder, f.eks. den siddende gruppe, og med påtegnede detaljer, bl.a. en gdende soldat midt $i$ og to gestikulerende soldater t.h. Solgt som postkort. Museet på Senderborg Slot.

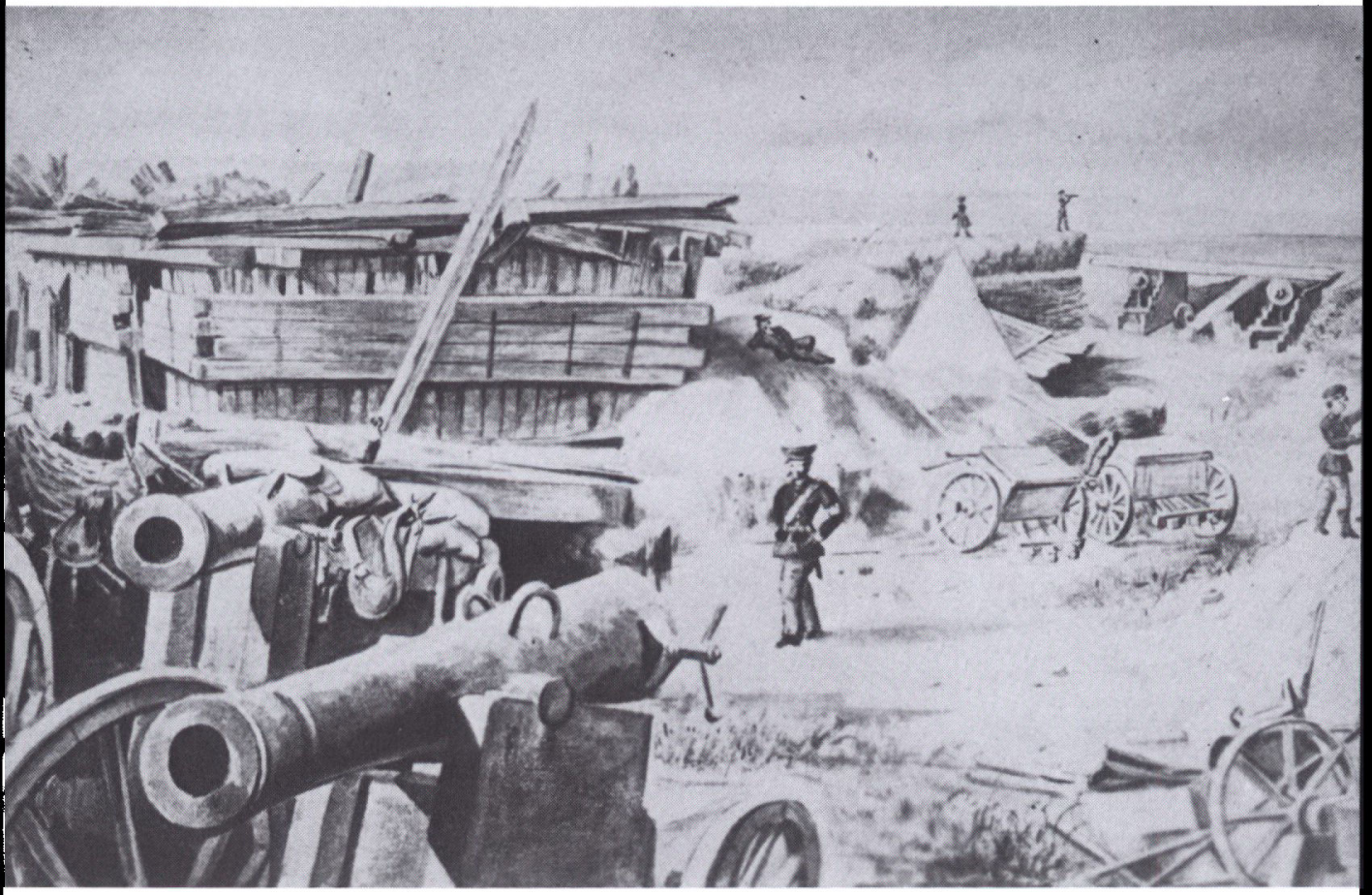




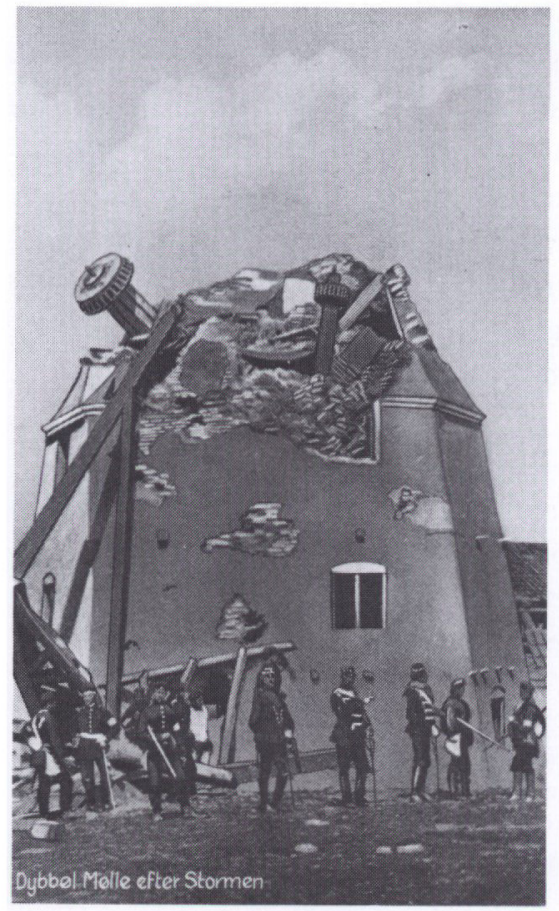

Prins Friedrich Carl af Preussen, overstbefalende for de tyske styrker, opstillet med sin stab foran den odelagte Dybbol Malle.

kanonparken i Adsbøl, hvor der er flere soldater på det ene, men kun en på det andet. Et andet sæt billeder er taget ved skanse 2 af C. Junod, begge udefra, men det ene med harver lagt ud foran skansen, det andet med rester af palisadepæle. Her er kameraet åbenbart flyttet nogle få meter mellem de to optagelser. Fra skanse 4 findes tre varianter af et Brandt-foto, hvor soldaterne findes i forskelligt antal og i lidt forskellige opstillinger. Tilsvarende findes adskillige andre eksempler på variationer i fotografier, der i øvrigt forestiller det samme. Nogle af disse ændringer skyldes retouche, mens de fleste nok er optagelser, udført med halve eller hele timers mellemrum.

En række af de billeder, der blev optaget i skanserne, blev imidlertid retoucherede så stærkt, at der næsten var tale om overmaling. Det kunne ske på positivet, der så på ny affotograferedes og mangfoldiggjordes ud fra det nye negativ eller det kunne ske på negativet, før der blev taget aftryk. En sådan overmaling er foretaget med flere billeder af C.Junod, og disse foreligger derfor i flere udgaver, af og til tre eller fire med det samme motiv. Ved flere af disse er det imidlertid uklart, om Junod også selv har ansvaret for den overmalede udgave. Normalt udsendes de retoucherede kopier nemlig ano- 


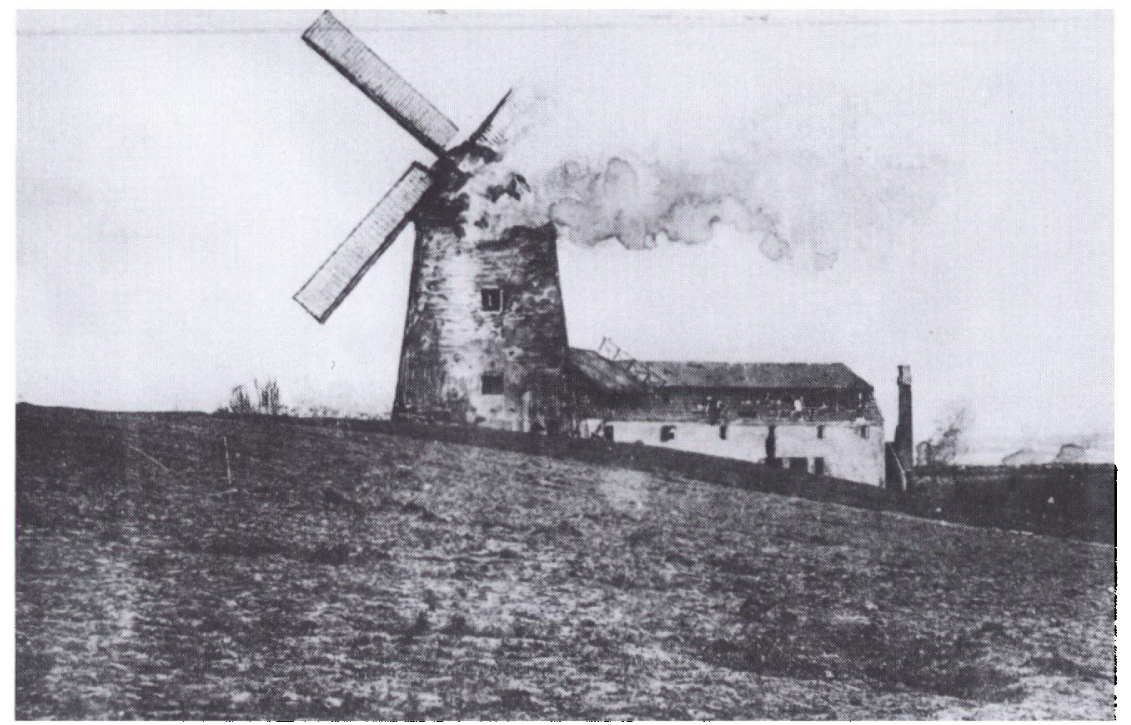

Det var ikke altid nok at vise den sonderskudte molle. Selve odelaggelsen var ogsa et godt motiv, men det var blot ikke fotograferet. Sd kunne man, som her, overmale et af C. Brandts fotografier og forsyne det med vinger og reg fra branden og derpd salge det som postkort. Museet på Sonderborg Slot.

Nogle få gange har en fotograf dog forsøgt at få det til at se ud, som om han havde optaget en krigsscene. Tydeligst er dette ved et billede, optaget af den tyske fotograf H.Graf eller hans medarbejder Halwass og solgt i flere udgaver med to forskellige titler: "Fægtning ved Øster-Dybbøl« (trykt på etikette på bagsiden) og "3. prøjs. Jæger-Bataillon rykker frem ved Graasten « (håndskrevet titel). Det sidste er nærmest sandheden, men der er nu ikke tale om fremrykning, men om en opstilling i fred og ro adskillige $\mathrm{km}$ fra fronten. Fotografen har haft den fornødne tid til at lede opstillingen, så man kunne få indtryk af, at soldaterne var klar til kamp og til at fotografere, mens alle stod pænt stille. ${ }^{44}$

Da kampene på Dybbøl var overstået, samledes det erobrede danske skyts sammen ved Nybøl. Her blev det fotograferet af Heinrich Graf fra Berlin. Kort efter udnævntes premierløjtnant Stöphasius fra 3. Brandenburgske Artilleribrigade til kommandant for den æres-eskorte, der i dagene fra 30. april til 24. maj førte de erobrede faner og kanoner til Berlin. Her fremstillede hoffotograf Hermann Günther nogle billeder af denne begivenhed, alle ved hjælp af en omstændelig montage. Som baggrund er en art malet kulisse med den nedskudte Dybbøl Mølle anbragt lidt forskelligt fra billede til billede. Foran 
dette ses forskellige sammenstillinger af soldater og kanoner. På det ene er ved hjælp af nogle gruppefotos, optaget $i$ et atelier, og et portrætfoto af Stöphasius, konstrueret et billede af hele den 120 mand store eskorte. På et andet vises prins Friedrich Carl og Stöphasius sammen med en mindre del af eskorten og en del af skytset, igen på en malet baggrund og igen sat sammen af portrætfotos og gruppebilleder. Der er endda foran tilføjet nogle faldne soldater. Et tredie viser på ny Stöphasius, men af eskorten er nu kun fire gruppebilleder og et par enkeltbilleder af 16 stående soldater og en opstilling med tre knælende soldater anvendt i montagen, hvor også skytset er sammenklippet fra flere billeder og endda suppleret med tegnede enkeltheder. ${ }^{45}$ Hermann Günther optog også 10 forskellige fotos af danske kanoner i Berlin og udgav dem samlet, ligesom han optog en gruppe på 8 stående soldater fra det 35. Brandenburgske Füsilier-Regiment. ${ }^{46}$ Han har givetvis optaget talrige gruppefotos og portrætter af soldater enkeltvis, og det er en del af disse, han har anvendt $\mathrm{i}$ sine fotomontager.

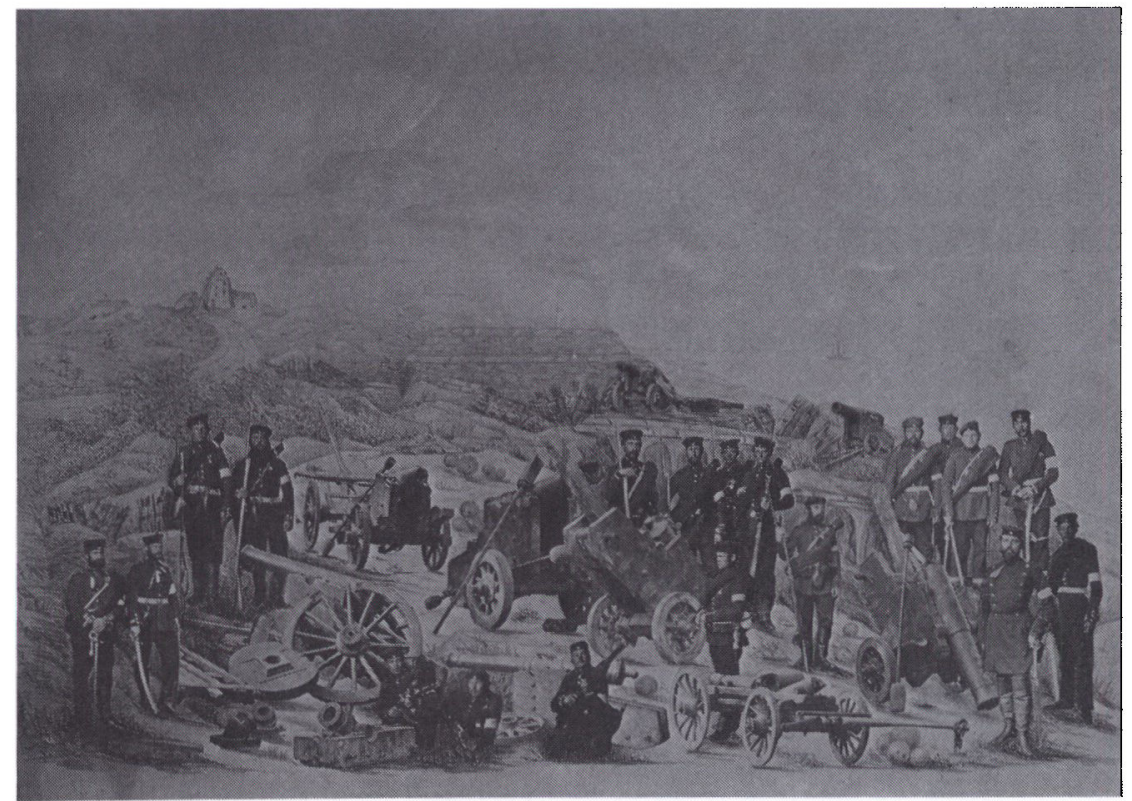

Fotomontage med en kombination af tegning og forskellige fotografier, udfort af fotograf H. Günther, Berlin. Billedet er et af en serie, der viser premierlojtnant Stöphasius, som forer det erobrede danske artilleri under eskorte til Berlin. Stöphasius ses forrest t.h. i billedet, stottet til sin sabel. Soldaterne er optaget enkelt- eller gruppevis, ligesom kanonerne er fotograferet hver for sig og sat ind på billedet. Museet pà Sonderborg Slot. 
Selv om der således var talrige fotografer, der var virksomme under krigen i 1864, var resultaterne ikke uden videre virkelighedstro reportagebilleder. Retouchering, overmaling af både negativer og positiver og brug af fotomontage kendtes allerede på dette tidlige tidspunkt, da fotograferingen netop var 25 år gammel. Alle disse muligheder udnyttedes flittigt. Det er derfor nødvendigt også over for disse meget tidlige billeder at være kritisk og at se nøje på de enkelte fotos for at afgøre, om det er uændrede originaler eller om der i større eller mindre grad er ændret på de enkelte gengivelser.

\section{LITTERATURLISTE}

Inge Adriansen: 1864 i samtidens aviser. Kbhvn. 1976.

Inge Adriansen: De sønderjyske piger. Sønderjyske Årbøger, 1988, s. 5-42. Også som særtryk.

Bibliografi og Ikonografi 1864. Udg. af Det kgl. Bibliotek og Schleswig-Holsteinisches Landesbibliothek, Kiel-Neumünster, 1970.

Axel Bolvig: Billeder - sådan set. København 1974.

Axel Bolvig: Den billedskabte virkelighed. København 1978.

Gail Buckland: Reality Recorded. Early Documentary Photography, London 1974.

Patrick Daniels: Early Photography, London 1978.

Rainer Fabian und H.Chr.Adam: Bilder vom Krieg. Hamb. 1983.

Fotografier - Charlottenborg. Et udvalg af Det kongelige Biblioteks samling. Udstilling Kbhvn. 1986.

Jesper Frederiksen: Fotografiet, fotografen - og os andre. Kbhvn. 1976.

Helmuth og Allison Gernsheim: Fotografiens historie. 1966. Udvidet engelsk udg. 1969.

Renate og L. Fritz Gruber: The imaginary Photomuseum. New York, 1982.

John Hannavy: Masters of Victorian Photography. London, 1976.

Jan S. Kunstreich: Frühe Photographen in Schleswig-Holstein, Heide, 1985.

Michael Langford: Fotografiens historie. Da. udg. v. Bj.Ochsner, Kbhn. 1981.

B. Newhall: The History of Photography from 1839 to the Present. London 1982.

Bjørn Ochsner: Fotografiet i Danmark 1840-1940. Kbhvn. 1974.

Bjørn Ochsner: Fotografer i og fra Danmark til og med år 1920. I-II, Kbhvn. 1986.

S.U.Palme og A.Meyersson: Historia genom kameraögat. I-II, Stockholm, 1958-59.

Rasmus Reeh: Fotografilovens historie og andre essays. Kbhvn. 1985.

J.Slettebo: Sønderborgs Bombardement i: Fra Als og Sundeved, 42, 1963.

J.Slettebo: Folkelig propaganda under Treårskrigen. I: Sdj. Årbøger, 1964, s. 126-146.

J.Slettebo: Gamle fotografier fra Als og Sundeved. Fra Als og Sundeved 55, 1977.

J.Slettebo og F.S.Grove-Stephensen: Sønderborg i 1864. i: By og Bolig. Fra Als og Sundeved, 66, 1988, s. 23-32.

Susan Sontag: Fotografi. Essays om billeder og virkelighed. Kbhvn. 1985, oversat fra engelsk. 


\section{NOTER}

1. H. og A.Gernsheim, 1966. S.U.Palme og A.Meyersson, 1958-59, J.Hannavy, 1976, s. 7-26. P. Daniels, 1978, s. 5-18, B. Newhall, 1982, s. 13-26, B.Ochsner, 1974, s. 5ff., J.Frederiksen, 1976, s. 17-29, J.Slettebo 1977 , s. 9-13.

2. H. og A.Gernsheim, 1966. G.Buckland, 1974, kap. 4 og 5. M.Langford, 1981, afsnit 6. B. Newhall, 1982, især s. 85-93.

3. J.Slettebo, 1964, især s. 133-136.

4. R. Fabian og H.C.Adam, 1983, s. 77.

5. G. Buckland, 1974, s. 62 f.

6. R.Fabian og H.C.Adam, 1983, s. 46 og 77.

7. B.Ochsner, 1986, s. 461 og 168. J.S. Kunstreich, 1985, s. 16 f.

8. B. Ochsner, 1986, s. 278.

9. G.Buckland, 1974, s. 59ff. og 83. J.Hannavy, 1976 s. 66-68. R. Fabian og H.C.Adam, 1983, s. 75-81. B. Newhall, 1982, s. 85-88.

10. R. Fabian og H.C.Adam, 1983, s. 82.

11. R. Fabian og H.C.Adam, 1983, s. 64-71 og 83-86. G.Buckland, s. 69-73. Gruber, fol 39-42 og 420.

12. J.Hannavy, 1976, s. 36f., G. Buckland, 1974, s. 98; B. Newhall, 1982, s. 64ff. P.Daniels, 1978, s. 31f. B.Ochsner, 1974, s. 8.

13. G. Buckland, 1974, s. 98; J.Frederiksen, 1976, s. 46-49.

14. E. og S.K. Larsen: Hvedholm Lazareth. Utrykt manuskript, 1983, s. 51. Forfatterne takkes for tilladelsen til at benytte deres arbejde.

15. B. Ochsner, 1986, s. 728 og 764.

16. B.Ochsner, 1986, alfabetisk under de enkelte navne. Billedarkivet i Museet på Sønderborg Slot har soldaterfotos af bl.a. de fleste af de her opremsede fotografer.

17. Iconografi 1864,1970 , især s. 251-62, jvf. iøvrigt note 16 .

18. Iconografi 1864, 1970, især s. 160-164 og s. 245-262 samt som note 16 .

19. J.Slettebo, 1977, s. 20.

20. Ikonografi 1864, 1970, m. henvisn. i registret s. 332f. og 339f. Billedeksempler i Mus. p. Sønderborg Slot, billedarkivet.

21. Ikonografi 1864,1970 , registret s. $311 \mathrm{ff} ., 317 \mathrm{f} ., 324 \mathrm{f}$.

22. B. Ochsner, 1986, s. 184-191, 250, 384 og 490.

23. Iconografi $1864,1970 \mathrm{nr} .5918$ og 5937. B. Ochsner, 1986, s. 155.

24. B. Ochsner, 1986, s. 123 og 840 . J.Slettebo, 1977, s. 17, 96 og 102.

25. B. Ochsner, 1986, s. 750 .

26. Ikonografi 1864, 1970, især afsnit III, 6-8. B.Ochsner, 1986, s. 448-50.

27. Ikonografi 1864, 1970, især afsnit III, 6-8. B.Ochsner, 1986, s. 184-191. J.Kunstreich, 1985, s. 29-32. J.Slettebo, 1977, s. 19 og 22-27.

28. A. Bolvig, 1974, s. 78-79.

29. Politiken 28-02-1987.

30. J.Frederiksen, 1976.

31. Institut for sønderjysk lokalhistorie, H.Fangel takkes for hjelp ved fremskaffelse af materiale fra instituttets billedsamling.

32. H. og A.Gernsheim, 1969 s. 186.

33. B.Ochsner, 1986, s. 665 og 338 .

34. B.Ochsner, 1986, 768.

35. B. Ochsner, 1986 , s. 180.

36. B. Ochsner, 1986, s. 370,198 og 638.

37. M.Langford, 1981, s. 31ff. og 99-102. P. Daniels, 1978, s. 75.

38. I.Adriansen, 1988. s. 8-14.

39. F. Brandt har på sine skansebilleder trykt: »Mit gesetzlicher Schutz gegen Nachbildung«, mens 
Junod på nogle af sine billeder meddeler: "Vervielfältigung strenge verfolgt $\ll$. Jvf. R. Reeh, 1985, især s. 9-40 om den første danske fotografilov 1864 .

40. I.Adriansen, 1988, s. 39. B. Ochsner, 1986, s. 633.

41. Iconografi 1864, 1970, nr. 4804, 4812, 4843, 4861, 4882, 4891, 4895, 4906 og 4919. Eksemplarer af disse 9 fotografier befinder sig i Mus. p. Sdb. Sl.

42. Iconografi 1864, 1970, nr. 4938. Eks. i Dansk Centralbibl., Flbg.

43. Iconografi 1864, 1970, nr. 4936 og 4942. Eksemplar i Det kgl. Bibl.

44. Iconografi 1864, 1970, nr. 4458 og 4461.

45. Mus. på Sønderborg Slot, 1977.

46. Iconografi 1864, 1970, nr. 5706-15, 6476. 